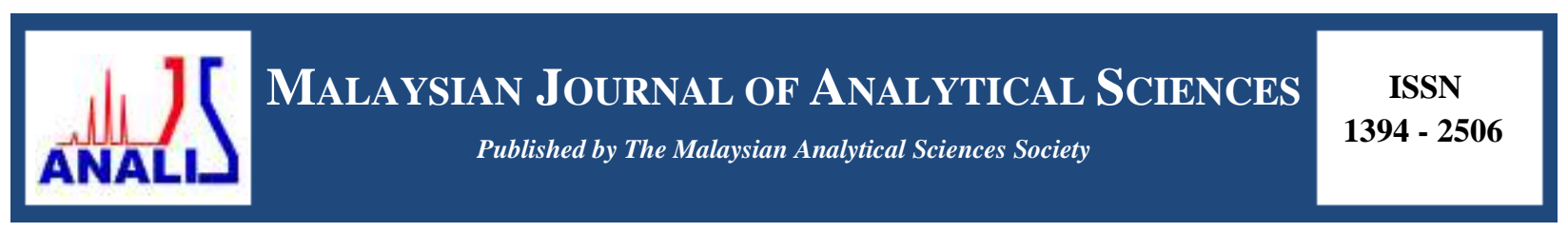

\title{
ADSORPTION OF Cu, As, Pb AND Zn BY BANANA TRUNK
}

\author{
(Penjerapan $\mathrm{Cu}$, As, $\mathrm{Pb}$ dan Zn oleh Batang Pisang) \\ Nurzulaifa Shaheera Erne Mohd Yasim ${ }^{1}$, Zitty Sarah Ismail ${ }^{1}$, Suhanom Mohd Zaki ${ }^{2}$, Mohd Fahmi Abd Azis ${ }^{1}$ \\ ${ }^{1}$ Faculty of Applied Sciences, \\ Universiti Teknologi MARA, 40450 Shah Alam, Selangor, Malaysia \\ ${ }^{2}$ Faculty of Business Management, \\ Universiti Teknologi MARA, 26400 Bandar Tun Razak Jengka, Pahang, Malaysia \\ *Corresponding author: nurzulaifa@salam.uitm.edu.my
}

Received: 9 December 2014; Accepted: 16 October 2015

\begin{abstract}
The purpose of this study is to investigate the effectiveness of banana trunk as an adsorbent in removal of heavy metals in aqueous solution. Functional groups of adsorbent were determined using Fourier Transform Infrared spectroscopy (FTIR). Batch experiments were conducted to determine the adsorption percentage of heavy metals $(\mathrm{Cu}, \mathrm{As}, \mathrm{Pb}$ and $\mathrm{Zn})$. The optimum adsorption using banana trunk was based on $\mathrm{pH}$ difference, contact time and dosage. Adsorption percentage was found to be proportional to $\mathrm{pH}$, contact time and dosage. Maximum adsorption percentage of $\mathrm{Cu}, \mathrm{As}, \mathrm{Pb}$ and $\mathrm{Zn}$ at $\mathrm{pH} 6,100$ minutes and 8 gram of dosage are $95.80 \%, 75.40 \%, 99.36 \%$ and $97.24 \%$, respectively. Langmuir and Freundlich isotherms were used to determine the equilibrium state for heavy metals ion adsorption experiments. All equilibrium heavy metals were well explained by the Freundlich isotherm model with $\mathrm{R}^{2}=0.9441, \mathrm{R}^{2}=0.8671, \mathrm{R}^{2}=0.9489$ and $\mathrm{R}^{2}=0.9375 \mathrm{for} \mathrm{Cu}, \mathrm{As}, \mathrm{Pb}$ and $\mathrm{Zn}$ respectively. It is concluded that banana trunk has considerable potential for the removal of heavy metals from aqueous solution.
\end{abstract}

Keywords: adsorption, heavy metals, banana trunk, $\mathrm{pH}$, contact time

\section{Abstrak}

Kajian ini bertujuan untuk menyiasat keberkesanan batang pisang sebagai penjerap dalam penyingkiran logam berat di dalam larutan akueus. Kumpulan berfungsi penjerap ditentukan menggunakan Spektrospkopi Infra Merah Transformasi Fourier (FTIR). Eksperimen kelompok dilakukan untuk menentukan peratusan penjerapan logam berat ( $\mathrm{Cu}, \mathrm{As}, \mathrm{Pb}$ dan $\mathrm{Zn})$. Penjerapan optimum menggunakan batang pisang berdasarkan $\mathrm{pH}$ yang berbeza, masa sentuhan dan dos penjerap dianalisis dalam eksperimen kelompok. Peratus penjerapan didapati berkadar terus dengan $\mathrm{pH}$, masa sentuhan dan dos penjerap. Peratus penjerapan maksimum $\mathrm{Cu}, \mathrm{As}, \mathrm{Pb}$ dan $\mathrm{Zn}$ pada $\mathrm{pH}$ 6, 10 minit masa sentuhan dan 8 gram dos penjerap masing-masing ialah $95.80 \%, 75.40$ $\%, 99.36 \%$ dan $97.24 \%$. Isoterma Langmuir dan Freundlich telah digunakan untuk menentukan keadaan keseimbangan bagi eksperimen penjerapan logam berat. Semua keseimbangan logam berat dijelaskan dengan baik oleh model isoterma Freundlich dengan $\mathrm{R}^{2}=0.9441, \mathrm{R}^{2}=0.8671, \mathrm{R}^{2}=0.9489$ dan $\mathrm{R}^{2}=0.9375$ masing - masing untuk logam $\mathrm{Cu}, \mathrm{As}, \mathrm{Pb}$ dan $\mathrm{Zn} . \mathrm{Dapat}$ disimpulkan bahawa batang pisang mempunyai potensi besar untuk penyingkiran logam berat daripada larutan akues.

Kata kunci: penjerapan, logam berat, batang pisang, $\mathrm{pH}$, masa sentuhan

\section{Introduction}

The presence of heavy metals in the water bodies has caused severe health effects to people. Too much ingestion of copper $(\mathrm{Cu})$ may bring about serious toxicological concerns, such as convulsions, vomiting, cramps or even death [1] while its deficiency may cause excessive accumulation of zinc ( $\mathrm{Zn}$ ) in human and animals which can reduce the immune system function. Among other effects include anemia, death of fetuses, liver, pancreas and kidney damage 
[2]. Arsenic (As) is known as a poisonous element and very toxic to human. It can cause cancer and skin disorder besides non-cancerous diseases such as cardiovascular, pulmonary and neurological problems. Meanwhile, exposure to lead $(\mathrm{Pb})$ resulted in a wide range of biological effects depending on the level and duration of the exposure.

Heavy metal sources can be natural or anthropogenic in origin. They existed naturally in a small amount on the Earth's crust and could not be degraded or eliminated. Higher concentration of heavy metals in the environment usually comes from anthropogenic activities such as copper $(\mathrm{Cu})$ from electricity conductor, building materials and various alloys constituents. Zinc $(\mathrm{Zn})$ is one of the transition elements possibly from refining and extraction industry while arsenic is contributed by human activities such as sewage and toxic chemicals disposals, industrial activities, vehicular emissions and erosion [3]. Finally, lead $(\mathrm{Pb})$ is possibly coming from several other sources such as petrol, industrial processing, painting and soldering industries, water pathways and piping [4].

There are several conventional methods in removing heavy metals from water, which include precipitation, ion exchange, reverse osmosis, electrocoagulation and nanofiltration [5 - 7]. However, these methods are limited for the use of large industries since the operational cost is high [8]. Thus, using waste materials as an absorbent over activated carbon in removing heavy metals is wisely suggested since they are cheaper and effective.

The major aim of this study is to determine the potential of banana trunk as an adsorbent in removal of heavy metals in aqueous solution. Banana trunk is an agricultural waste generated from agricultural activities. It is chosen due to the waste generated is rising dramatically which can risk both human and ecosystem [9]. This waste can be converted into useful products through recycle which subsequently minimize the level of pollution caused by agricultural burning activities. From previous studies, agricultural wastes are potentially low cost adsorbent as they are unexploited resources, widely available, environmental friendly and also natural materials that exist in large quantities [10]. Many research had been conducted such as the study of the removal of $\mathrm{Pb}$ (II) by citrus pectin [11] and adsorption of Fe (II) using tamarind bark (Tamarindus indica) and potato peel waste (Solanum tuberosum) [12]. The optimum adsorption process was identified as a function of $\mathrm{pH}$, contact time and dosage.

\section{Chemical and stock preparation}

\section{Materials and Methods}

$5 \mathrm{ppm}$ of each heavy metal solution was prepared from $100 \mathrm{ppm}$ stock solution through dilution. The metal solutions were adjusted to $\mathrm{pH} 5$ using $0.1 \mathrm{M}$ of hydrochloric acid ( $\mathrm{HCl})$ [13]. It is recommended to shake the stock solution thoroughly prior to use and must not pipette directly from the bottle.

\section{Sample preparation and analysis}

The samples of banana trunk were obtained from banana plantation in Kuang, Selangor. The trunks were sliced into small pieces and washed thoroughly using distilled water. The trunks were air-dried for $4-5$ hours before keeping them in the oven for 24 hours at $50{ }^{\circ} \mathrm{C}$. Then, the dried trunks were grounded and sieved and ready for FTIRanalysis [14]. This analysis is to determine the functional groups in banana trunk by scanning the sample from 4000 to $400 \mathrm{~cm}^{-1}$ at a $400 \mathrm{~cm}^{-1}$ resolution [15].

\section{Batch analysis}

$50 \mathrm{~mL}$ of $5 \mathrm{ppm}$ metal solution was mixed with $2 \mathrm{~g}$ of adsorbent in $250 \mathrm{~mL}$ flasks and agitated at $100 \mathrm{rpm}$ for 60 min using an orbital shaker. The experiment was continued to identify the adsorption equilibrium dosage through mixing the solution with $4-10 \mathrm{~g}$ of dosage. The suspension was then separated by decantation. Determination of the rate of adsorption and adsorption equilibrium time was performed by determining the residual metal solution in the supernatant by allowing metal support-banana trunk fibers sorbent to equilibrate at different $\mathrm{pH}$ values of 2-10 for $60 \mathrm{~min}$. Then, at the optimum $\mathrm{pH}$ and dosage, metal support-banana trunks were allowed to contact at different period between $5-150 \mathrm{~min}$. The residual metal ion concentration was analyzed using Inductively Coupled PlasmaOptical Emission Spectrometer (ICP-OES). The percentage removal of heavy metal was calculated as equation 1 below:

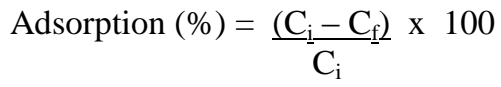

where, $\mathrm{C}_{\mathrm{i}}$ and $\mathrm{C}_{\mathrm{f}}$ are the initial and final concentrations of heavy metals present in the adsorption studies. 


\section{Adsorption isotherm}

Analysis of adsorption under constant temperature was studied by using Langmuir and Freundlich equations. Langmuir isotherm assumes that there is an infinite number of binding sites having the same affinity for adsorption of mono layer and there is no interaction between the adsorbed molecules [16]. Based on the assumption, Langmuir isotherm represents the following equation 2 :

$$
\mathrm{q}_{\mathrm{e}}=\frac{\mathrm{q}_{\mathrm{m}}}{1+\mathrm{K}_{\mathrm{L}}} \underline{\mathrm{K}}_{\mathrm{L}} \underline{\mathrm{C}}_{\mathrm{e}}
$$

The Langmiur equation is transformed into linear form to determine Langmiur adsorption parameters as expressed in Equation 3 below;

$$
1 / \mathrm{q}_{\mathrm{e}}=\left(1 / \mathrm{q}_{\mathrm{m}}\right)+\left(1 / \mathrm{q}_{\mathrm{m}} \mathrm{K}_{\mathrm{L}}\right)\left(1 / \mathrm{C}_{\mathrm{e}}\right)
$$

where $\mathrm{q}_{\mathrm{e}}(\mathrm{mg} / \mathrm{g})$ and $\mathrm{q}_{\mathrm{m}}(\mathrm{mg} / \mathrm{g})$ are the amount of adsorbed metal ions per unit mass of adsorbent and adsorption capacity, respectively. $\mathrm{K}_{\mathrm{L}}$ is a constant related to the affinity of the binding sites $(\mathrm{L} / \mathrm{mg})$ and $\mathrm{C}_{\mathrm{e}}$ is a un-adsorbed metal ion concentration in solution at equilibrium $(\mathrm{mg} / \mathrm{L})$.

The assumption of Freundlich isotherm is the adsorption energy of a metal binding to a site on an adsorbent depends on the vacancies of the adjacent sites and it is expressed by the following equation 4 [17]:

$$
\mathrm{q}_{\mathrm{e}}=\mathrm{K}_{\mathrm{F}} \mathrm{C}_{\mathrm{e}}{ }^{1 / \mathrm{n}}
$$

In linear form, the Freundlich equation is expressed as follows:

$$
\log \mathrm{q}_{\mathrm{e}}=\log \mathrm{K}_{\mathrm{F}}+1 / \mathrm{n} \log \mathrm{C}_{\mathrm{e}}
$$

where $\mathrm{q}_{\mathrm{e}}$ the amount of metals adsorbed per unit mass of adsorbent $(\mathrm{mg} / \mathrm{g}) ; \mathrm{C}_{\mathrm{e}}$ is the equilibrium concentration of metal ions $(\mathrm{mg} / \mathrm{L})$ while $\mathrm{K}_{\mathrm{F}}\left(\mathrm{mg} / \mathrm{g}(\mathrm{L} / \mathrm{mg})^{1 / \mathrm{n}}\right)$ and $n$ (dimensionless) signify the adsorption capacity and adsorption intensity respectively. It can be defined as the adsorption or distribution coefficient and represents the quantity of dye adsorbed onto adsorbent for unit equilibrium concentration. $1 / n$ is the heterogeneity factor and $n$ is a measurement of the deviation from linearity of adsorption. The values indicate the degree of non-linearity between solution concentration and adsorption. The interpretations are as follow: If the value of $n$ is equal to unity, the adsorption is linear; if the value is below unity, this implies that adsorption process is chemical, if the value is above unity adsorption is a favorable physical process.

\section{Characterization of adsorbent}

\section{Results and Discussion}

Based on the FTIR spectrum of banana trunk biomass shown in Figure 1, three different absorption peaks were detected. The peak at $3400.84 \mathrm{~cm}^{-1}$ represents the $\mathrm{O}-\mathrm{H}$ functional group. The absorption band at $1624.01 \mathrm{~cm}^{-1}$ occurred for primary amine N-H functional group while the carboxylic acid (-COOH) group were detected at $1054.52 \mathrm{~cm}^{-1}$ wavelength. Previous study had stated that hydroxyl and carboxylic acid groups played a major role in the adsorption process [18]. According to [19], the hydroxyl group is highly effective towards adsorption rate and efficient through the exchange with metal ions. Meanwhile, the carboxylic acid group is relatively high adsorption rate due to the presence of more negatively charged groups on its surface [20].

\section{Effect of adsorbent dosage}

The effect of adsorbent dosage on the removal of selected heavy metals was investigated and shown in Figure 2 . At the initial stage of batch experiment, the adsorption percentage of heavy metals increased with increasing of adsorbent dosage. This is probably due to the fact that by increasing the adsorbent dosage there will be numbers of active sites available for the adsorption of metal ions. However, further expansion of adsorbent dosage (> $8 \mathrm{~g}) \mathrm{did}$ not significantly affect the percentage removal of heavy metals due to overcrowding of adsorbent particles [21]. 
Nurzulaifa Shaheera Erne et al: ADSORPTION OF Cu, As, Pb AND Zn BY BANANA TRUNK

Hence, the optimum dosage of banana trunk biomass for removing metal ions from liquid phase was 8 gram.

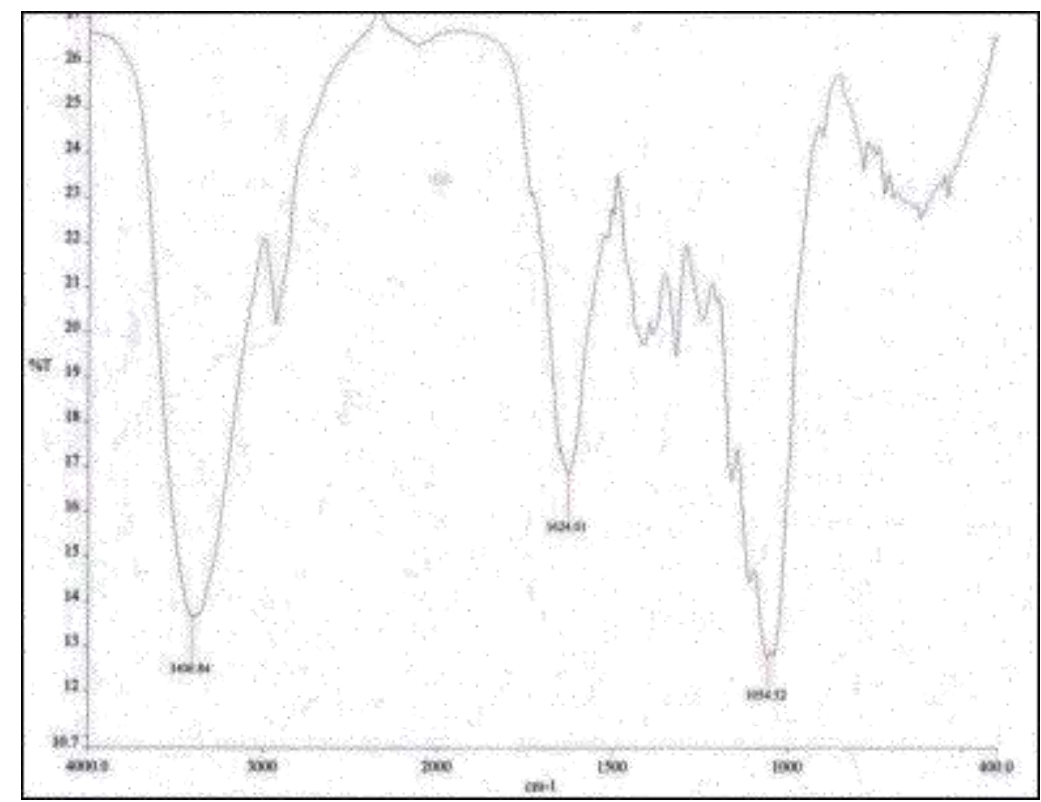

Figure 1. FTIR spectrum of banana trunk biomass $\left(4000 \mathrm{~cm}^{-1}-400 \mathrm{~cm}^{-1}\right)$

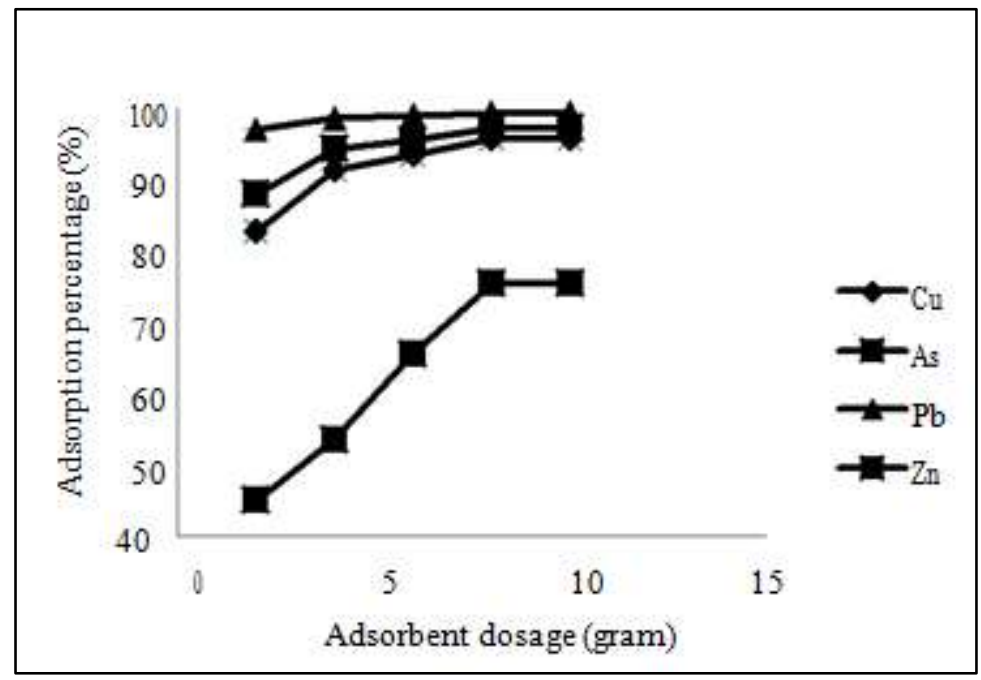

Figure 2. Graph of adsorbent dosage versus adsorption percentage

\section{Effect of pH}

Figure 3 shows the relationship between the adsorption percentages with $\mathrm{pH}$ for all the four heavy metals. The results obtained showing that there was a rapid removal of metal ions followed by slower adsorption process until the optimum $\mathrm{pH}$ was reached $\mathrm{pH}$ 6. It was noticed that the adsorption percentages for all four metals remained 
constant as the $\mathrm{pH}$ increased beyond the optimum level. The tremendous metals removal as the $\mathrm{pH}$ increased is due to the reduction of competition between protons and metal cations for the same functional groups and by decreasing in the positive surface charge resulting in a lower electrostatic repulsion between the surface and metal ions [13]. It was recorded that the adsorption was at the least at the initial $\mathrm{pH} 2$. The low adsorption percentage at the $\mathrm{pH} 3$ and below is because of the $\mathrm{H}^{+}$ion competing with the metal cations for the adsorption site available whereas at the higher $\mathrm{pH}$, the adsorption site is not active.

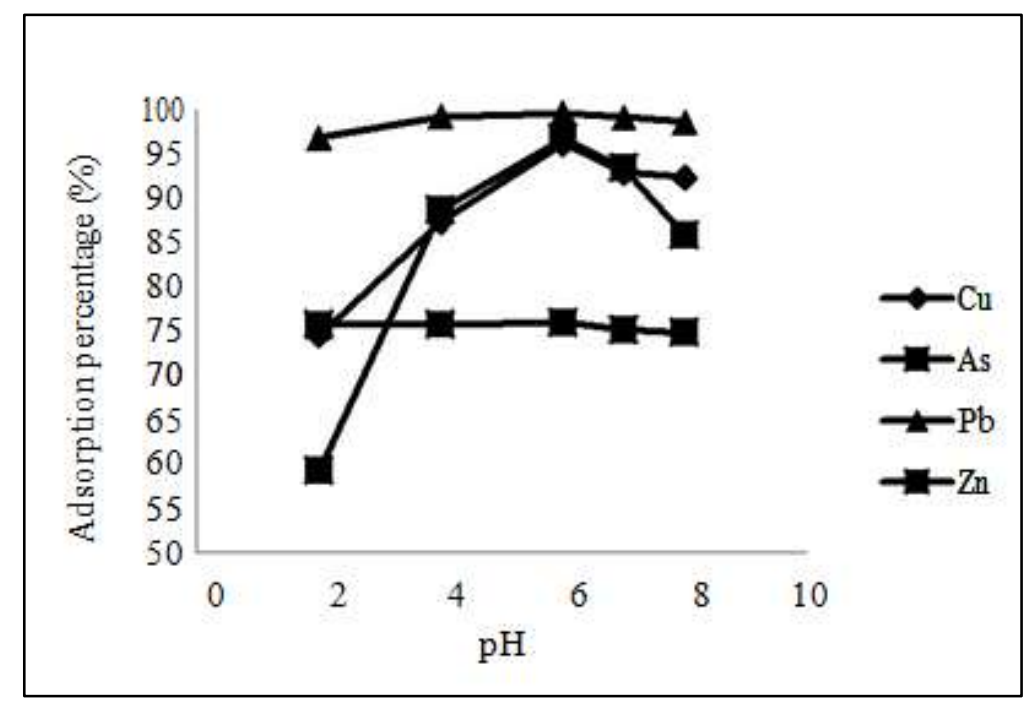

Figure 3. Graph of $\mathrm{pH}$ versus adsorption percentage

\section{Effect of contact time}

Optimum $\mathrm{pH}$ solutions were used for the determination of adsorption equilibrium time. Investigation of the effect of contact time in removal of heavy metals using banana trunk is explained in Figure 4. The removal of all four types heavy metal is increased with contact time until the optimum state is reached which was at $100 \mathrm{~min}$. By extending the contact time beyond the optimum state, the process of removal of heavy metals was not significantly effective. On the other hand, the adsorption percentage was decreased due to the accumulation of metal ion species [22].

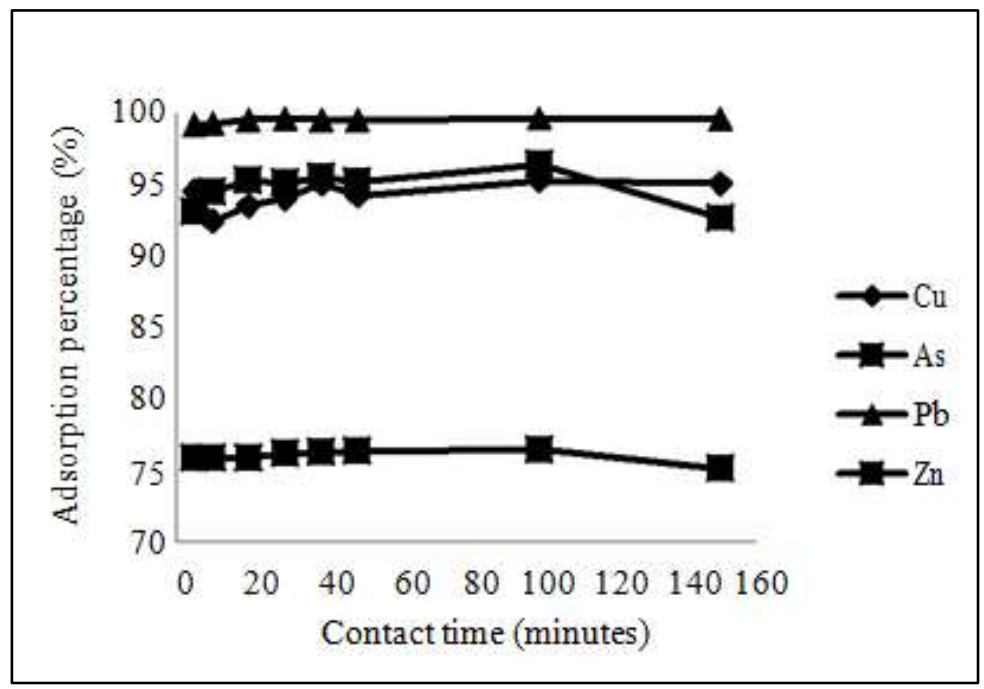

Figure 4. Graph of contact time versus adsorption percentage 


\section{Equilibrium studies}

Langmuir and Freundlich isotherms were used to describe the equilibrium state of metal ions adsorption. The uptakes occur on a homogenous surface by monolayer sorption without any interaction between adsorbent molecules is described by Langmuir isotherm. This isotherm assumes there are no transmigration of metal ions in the plane of the surface and uniform energies of adsorption onto the surface. Langmuir isotherm constants were obtained from the plot of $1 / \mathrm{q}_{\mathrm{e}}$ against $1 / \mathrm{C}_{\mathrm{e}}$. Heavy metals $(\mathrm{Cu}, \mathrm{As}, \mathrm{Pb}$ and $\mathrm{Zn})$ adsorptions that follow the Langmuir isotherm model are shown in Figure 5 whereas $1 / \mathrm{q}_{\mathrm{e}}$ was plotted against $1 / \mathrm{C}_{\mathrm{e}}$ and straight line was obtained for all studied heavy metals. The Langmuir parameters, $\mathrm{q}_{\mathrm{m}}$ and $\mathrm{K}_{\mathrm{L}}$ were calculated from the slope and interception of the isotherm as recorded in Table 1 . From the Langmuir parameter, the adsorption capacities, $\left(\mathrm{q}_{\mathrm{m}}\right)$, were identified in the sequence of $\mathrm{Cu}>\mathrm{Pb}>\mathrm{As}>\mathrm{Zn}$.

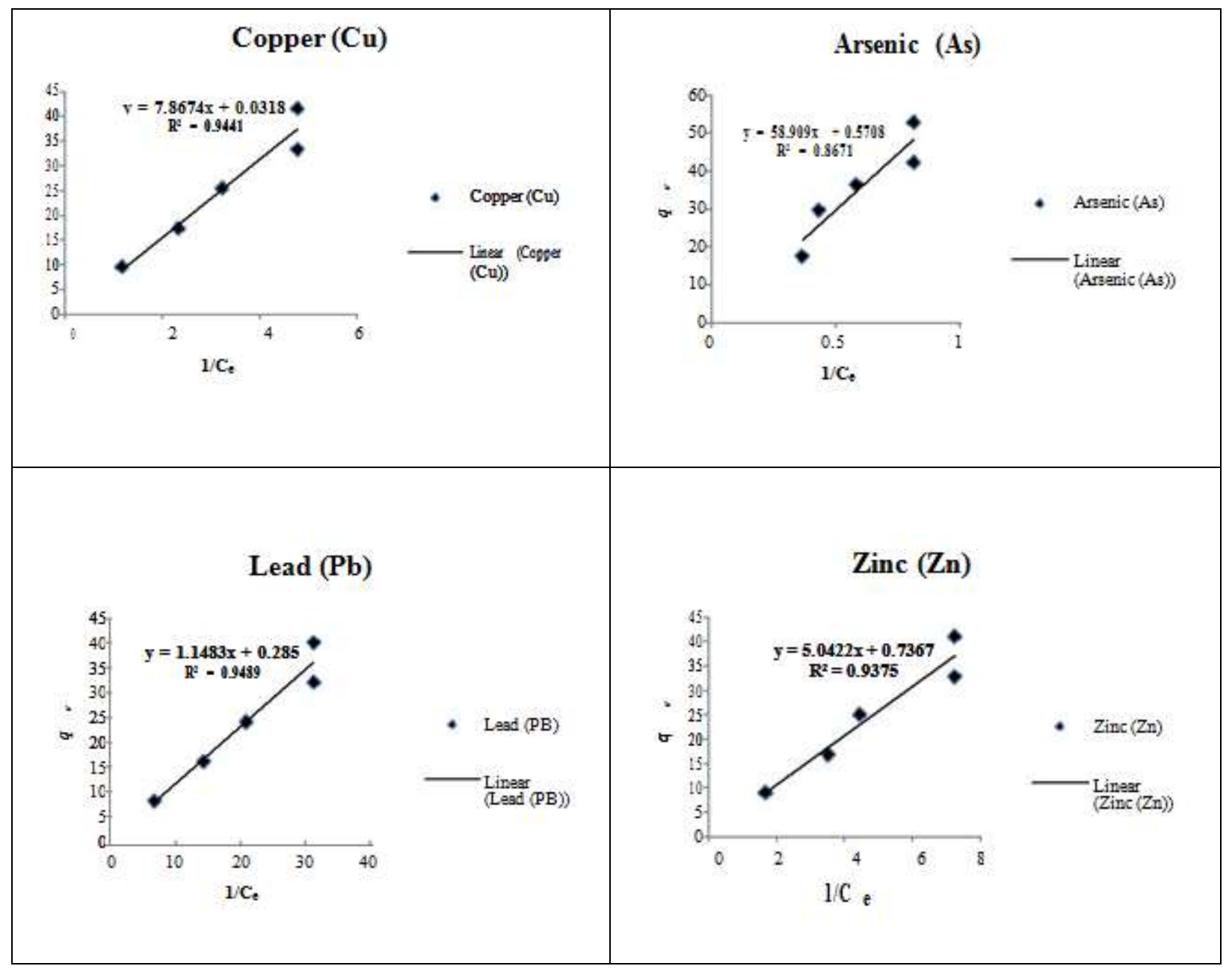

Figure 5. Plots of Langmiur isotherm for all heavy metals examined

The Freundlich isotherm describes the adsorption onto a heterogeneous surface. In Figure 6, when $\log \mathrm{C}_{\mathrm{e}}$ was plotted against $\log \mathrm{q}_{\mathrm{e}}$, straight line was obtained representing that metal ions adsorption has followed the Freundlich isotherm model. Freundlich parameters which include $n$ values and $\mathrm{K}_{\mathrm{F}}$ values were computed from the slope and interception of the isotherm. 


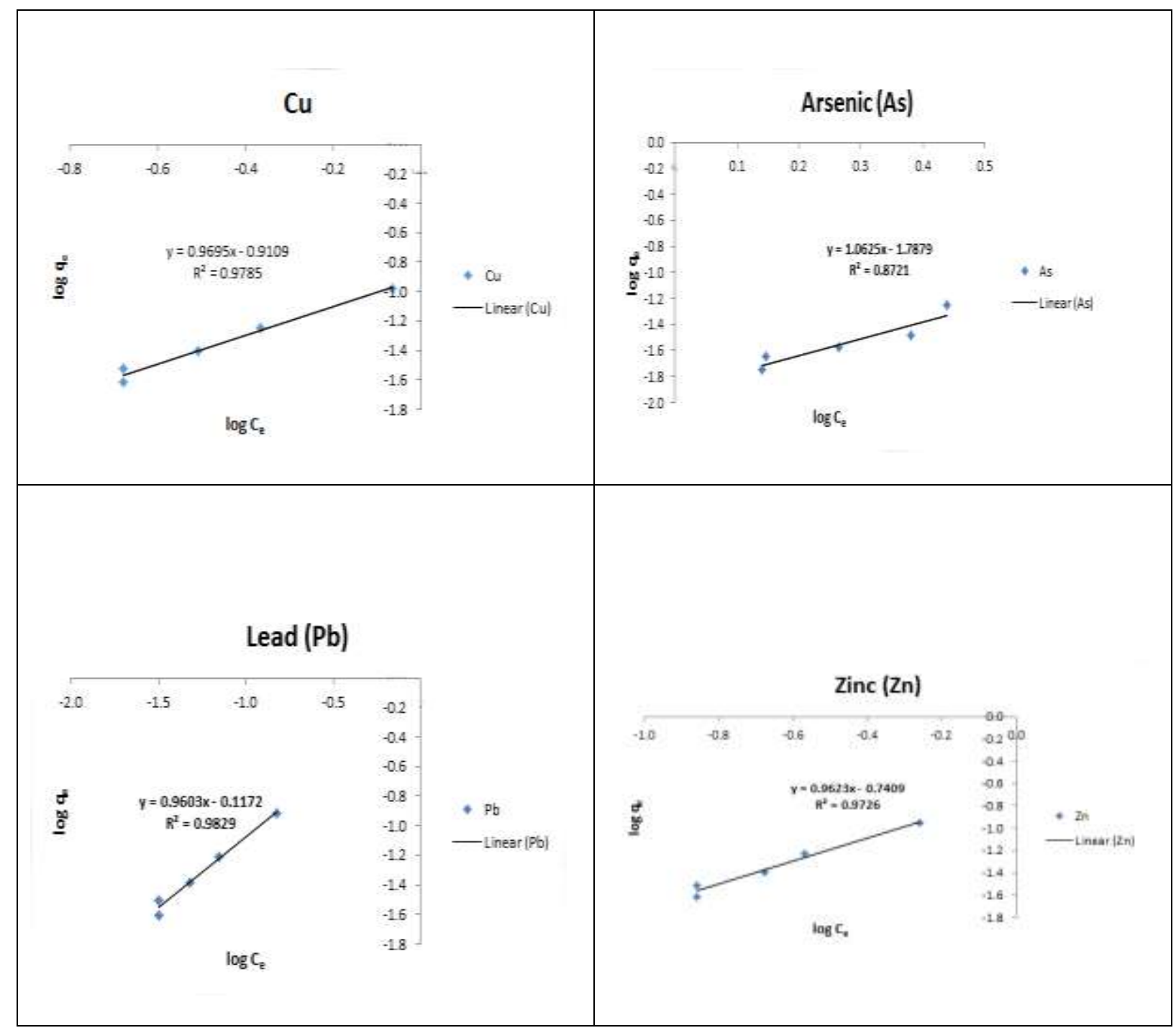

Figure 6. Plots of Freundlich isotherm for all heavy metals examined

Metal ions of $\mathrm{Cu}, \mathrm{Pb}$ and $\mathrm{Zn}$ were favorably adsorbed by adsorbent since the $\mathrm{n}$ values are greater than $1 . N$ values less than one indicate that the metal ions were not favorably adsorbed by adsorbent as shown in As adsorption. Table 2 shows the comparative evaluation of heterogeneous adsorption capacities onto various adsorbents.

The linear coefficient $\left(\mathrm{R}^{2}\right)$ was calculated to examine the fitness of the two isotherm models in the linear form. It is noted that Freundlich model describes the adsorption more successfully than Langmuir model where $\mathrm{R}^{2}$ values of Langmuir model for all investigated heavy metals is higher and closer to unity compared to Freundlich model. According to Nady and Iman [23], if $\mathrm{R}^{2}$ and $\mathrm{K}_{\mathrm{L}}<1$, it is shown that metal ions are highly favorable adsorbed by prepared adsorbent. Thus, in this study, it is confirmed that banana trunk is effective in removal of heavy metals from aqueous solution. 
Nurzulaifa Shaheera Erne et al: ADSORPTION OF Cu, As, Pb AND Zn BY BANANA TRUNK

Table 1. Langmuir and Freundlich parameters and correlation coefficient for the metals examined

\begin{tabular}{ccccccc}
\hline Heavy Metals & \multicolumn{3}{c}{ Langmuir Isotherm } & \multicolumn{3}{c}{ Freundlich Isotherm } \\
\cline { 2 - 7 } & $\mathbf{q}_{\mathbf{m}}$ & $\mathbf{K}_{\mathbf{L}}$ & $\mathbf{R}^{\mathbf{2}}$ & $\mathbf{n}$ & $\mathbf{K}_{\mathbf{L}}$ & $\mathbf{R}^{\mathbf{2}}$ \\
\hline $\mathrm{Cu}$ & 31.45 & $4.04 \times 10^{-3}$ & 0.9441 & 1.03 & 0.12 & 0.9785 \\
$\mathrm{As}$ & 1.75 & $9.70 \times 10^{-3}$ & 0.8671 & 0.94 & $1.63 \times 10^{-2}$ & 0.8721 \\
$\mathrm{~Pb}$ & 3.51 & 0.25 & 0.9489 & 1.04 & 0.76 & 0.9829 \\
$\mathrm{Zn}$ & 1.36 & 0.15 & 0.9375 & 1.04 & 0.18 & 0.9726 \\
\hline
\end{tabular}

Table 2. Comparative evaluation of heterogeneous adsorption capacities onto various adsorbents

\begin{tabular}{|c|c|c|c|}
\hline Metal & Adsorbent & $\begin{array}{c}\text { Heterogeneous } \\
\text { adsorption capacity } \\
(\mathrm{mg} / \mathrm{g})\end{array}$ & References \\
\hline \multirow{4}{*}{$\mathrm{Cu}$} & Banana trunk & 1.03 & Present study \\
\hline & Banana peel & 1.31 & [24] \\
\hline & Rock melon activated carbon & 0.59 & [25] \\
\hline & Potato peel & 1.86 & [26] \\
\hline \multirow{4}{*}{$\mathrm{Pb}$} & Banana trunk & 0.94 & Present study \\
\hline & Banana peel & 1.40 & [24] \\
\hline & Orange peel & 3.88 & [27] \\
\hline & Poly (vinyl alcohol)/chitosan & 1.69 & [28] \\
\hline \multirow{3}{*}{ As } & Banana trunk & 1.04 & Present study \\
\hline & Orange peel & 4.27 & [29] \\
\hline & Banana peel & 1.35 & [30] \\
\hline \multirow{4}{*}{$\mathrm{Zn}$} & Banana trunk & 1.04 & Present study \\
\hline & Banana peel & 1.58 & [24] \\
\hline & Potato peel & 1.74 & [26] \\
\hline & Canola & 1.85 & [26] \\
\hline
\end{tabular}

\section{Conclusion}

In the present study it is proven that banana trunk has potential to be an effective and economically feasible adsorbent in removal of heavy metals. Three $(\mathrm{Cu}, \mathrm{Pb}$ and $\mathrm{Zn})$ out of four heavy metals achieved more than $90 \%$ removals whereas As removal was only $75.40 \%$. In the batch experiment, it has been shown that the percentage removal is highly dependent on $\mathrm{pH}$, contact time and dosage. The highest percentage removal for all investigated heavy metals was found at optimum $\mathrm{pH} 6,100$ min of contact time and $8 \mathrm{~g}$ dosage. The effectiveness of banana trunk as adsorbent in removal of heavy metals is confirmed by FTIR result that has detected three functional groups 
including hydroxyl groups, carboxylic group and amine groups which played a major role in adsorption. The equilibrium adsorption data is best represented by Freundlich isotherm model compared to the Langmuir isotherm.

\section{Acknowledgement}

The authors would like to thank the University Teknologi MARA (UiTM) especially to Faculty of Applied Sciences, for giving the opportunity and providing the facilities to successfully perform this study.

\section{References}

1. Chen, T. C., Priambodo, R., Huang, R. L. and Huang, Y. H. (2013). The Effective Electrolytic Recovery of Dilute Copper from Industrial Wastewater. Journal of Waste Management. 2013: 1 - 6.

2. Perk, M. V. D. (2007). Soil and water contamination; from molecular to catchment scale. Utrecht, Netherland: Taylor \& Francis. 128.

3. Garba, Z. N. and Hamza, S. A. (2010). Arsenic level speciation in fresh water from Karaye, local government area, Kano state, Nigeria. International Journal Chemistry 20 (2): 113 - 117.

4. Tong, S., Schirnding, Y. E. V. and Prapamontol, T. (2000). Environmental lead exposure: a public health problem of global dimensions. Bulletin of the World Health Organization 78(9): 1068 - 1077.

5. Kumari, P., Sharma, P., Srivastava, S. and Srivastava, M. M. (2006). Biosorption studies on sheeled Moringa oleifera Lamarck seed powder: Removal and recovery of arsenic from aqueous system. International Journal of Mineral Processing 78(3): $131-139$.

6. Mondal, P., Majumder, C. B. and Mohanty, B. (2008). Treatment of arsenic water in a batch reactor by using ralstonia eutropha MTCC 2847 and granular activated carbon. Journal of Hazardous Materials 153(1-2): 588 599.

7. Rahman, M. S., Basu, A. and Islam, M. R. (2008). The removal of As (III) and As (V) from aqueous solutions by waste materials. Bioresource Technology. 99(8): 2815 - 2823.

8. Murugesan, G. S., Sathiskumar, M. and Swaminathan, K. (2006). Arsenic removal from groundwater by pretreated waste tea fungal biomass. Bioresource Technology. 97(3): 483 - 487.

9. Oladeji, Taiwo, J., Oyetunji and Ropo, O. (2013). Investigations into Physical and Fuel Characteristics of Briquettes Produced from Cassava and Yam Peels. Journal of Energy Technologies and Policy 3 (7): 40 - 46.

10. Deans, J. R. and Dixon, B. G. (1992). Uptake of $\mathrm{Pb}^{2+}$ and $\mathrm{Cu}^{2+}$ by novel biopolymers. Water Resource 26(4): $469-472$.

11. Ankit, B. and Silke, S. (2008). Assessment of biosorption mechanism for $\mathrm{Pb}$ binding by citrus pectin. Separation and Purification Technology 63(3): 577 - 581.

12. Prasad, D. and Abdulsalam (2009). Biosorption on Fe (II) from aqueous solution using Tamarind Bark and potato peel waste; equilibrium and kinectic studies. Journal Application Science in Environmental Sanitation 4(3): $273-282$.

13. Saeed, A., Akther, M. W. and Iqbal, M. (2005). Removal and recovery heavy metal from aqueous solution using papaya wood as a new biosorbent. Separation and Purification Technology 45 (1): 25 -31.

14. Kamsonlian, S., Balomajumder, C. and Chand, S. (2012). A potential of biosorbent derived from banana peel for removal of As (III) from contaminated water. Journal of Chemical Sciences and Applications 3(2): 268 275.

15. Sim, S. F., Murtedza, M., Lu, N. A. L. M. I., Sarman, N. S. P. and Samsudin, S. N. S. (2012). Computerassisted analysis of Fourier Transform Infrared (FTIR) spectra for characterization of various treated and untreated agriculture biomass. BioResources 7(4): $5367-5380$.

16. Ahmet, S. and Mustafa, T. (2008). Biosorption of total chromium from aqueous solution by red algae (ceramium virgatum): equilibrium, kinetic and thermodynamics studies. Journal of Hazardous Materials 160: $349-355$.

17. Shugi, K., Singh, T. S. and Pant, K. K. (2003). Equilibrium and kinetics studies on removal arsenite by iron oxide coated activated alumina. Indian Journal Environmental Health 45: 151 - 154.

18. Hossain, M. A., Ngo, H. H., Guo, W. S. and Nguyen, T. V. (2012). Biosorption of Cu (II) from water by banana peel based biosorbent: experiments and models of adsorption and desorption. Journal of Water Sustainability 2(1): 87 - 104.

19. Wu, H. X., Wang, T. J., Chen, L. and Jin, Y. (2009). The roles of the surface charge and hydroxyl group on a Fe-Al-Ce adsorbent in fluoride adsorption. Industrial Engineering Chemistry Research 48: 4530 - 4534. 
20. Chang, W. C., Deka, J. R., Wu, H. Y., Shieh, F. K., Huang, S. Y. and Kao, H. K. (2013). Synthesis and characterization of large pore cubic mesoporous silicas functionalized with high contents of carboxylic acid groups and their use as adsorbents. Applied Catalysis B: Environmental 142 - 143: 817 - 827.

21. Arunakumara, K. K. I. U., Buddhi, C. W. and Min-Ho, Y. (2013). Banana Peel: A Green Solution for Metal Removal from Contaminated Water. Korean Journal of Environmental Agriculuture 32 (2): 108 - 116.

22. Kamsonlian, S., Suresh, S., Majumder, C. B., Chand, S. (2011). Biosorption of As (V) from contaminated water onto tea waste biomass: sorption parameters optimization, equilibrium and thermodynamic studies. Journal of Future Engineering and Technology 7: 34 - 41.

23. Nady, A. F. and Iman, Y. E. S. (2011). Equilibrium Removal of Pb (II) Ions from Aqueous Solution onto Oxidized-KOH-Activated Carbons. Carbon Letters 12 (1): 1 - 7.

24. Muhammad, A. A., Abdul, W., Karamat, M., Mohd, J. M. and Ismail, Y. (2011). Low cos biosorbent banana peel (Musa sapientum) for the removal of heavy metals. Scientific Research and Essays 6 (19): 4055 - 4064.

25. Said, N., Amalina, R., Mazza, S. A. A., Syafiqah, A. K. and Hajar, A. M. S. (2015). Rock Melon Activated Carbon (RMAC) for Removal of Cd (II), Ni (II) and $\mathrm{Cu}$ (II) from Wastewater: Kinetics and Adsorption Equilibrium. International Journal of Chemical Engineering and Applications 6 (2): 105 - 110.

26. Morteza, F. and Mohsen, J. (2015). Removal of heavy metals from aqueous solution using sunflower, potato, canola and nut shell residues. Journal of the Taiwan Institute of Chemical Engineers 54: 125 - 136.

27. Ningchuan, F., Xueyi, G., Sha, L., Yanshu, Z. and Jianping, L. (2011). Biosorption of heavy metals from aqueous solutions by chemically modified orange peel. Journal of Hazardous Materials 185: 49 - 54.

28. Xiaoli, L., Yanfeng, L. and Zhengfang, Y. (2011). Preparation of macroporous bead adsorbents based on poly (vinyl alcohol)/chitosan and their adsorption properties for heavy metals from aqueous solution. Chemical Engineering Journal 178: 60 - 68

29. Suantak, K., Balomajumder, C. and Chand, S. (2012). Studies on surface characterization and isotherm modelling: Biosorption of Arsenic (III) onto low cost biosorbent derived from orange peel. Journal of Scientific and Industrial Research 71: $810-816$.

30. Suantak, K., Balomajumder, C. and Chand, S. (2012). A potential of biosorbent derived from banana peel for removal of As (III) from contaminated water. International Journal of Chemical Sciences and Applications 3 (2): $269-275$. 